\title{
STUDENT CHARACTERISTICS AND PERCEIVED SERVICE QUALITY TOWARDS SUSTAINABILITY OF HIGHER EDUCATIONAL INSTITUTIONS
}

\author{
SITI FALINDAH PADLEE, AZILAH SULAIMAN, MARHANA MOHAMED ANUAR, SITI \\ NUR 'ATIKAH ZULKIFFLI*, NOOR ZATUL IFFAH HUSSIN AND JUHAIZI MOHD YUSOF
}

Faculty of Business, Economics \& Social Development, Universiti Malaysia Terengganu, 21030 Kuala Nerus, Terengganu, Malaysia.

*Corresponding author: atikahzulkiffli@umt.edu.my

Submitted final draft: 23 July $2020 \quad$ Accepted: 22 June 2020

http://doi.org/10.46754/jssm.2021.04.016

\begin{abstract}
The aim of this paper is to examine the influence of students' differences in gender, nationality, and educational level on their perception to the educational attributes of teaching quality, research quality, and internationalisation quality of the Malaysia Public Research Higher Education Institutions (MPRHEIs) in meeting the challenge of global sustainability. 500 students from five MPRHEIs were selected as the respondents of the study, which comprise undergraduates in their second year and above as well as local and international postgraduates. A total of 418 questionnaires were collected from the respondents and inferential statistics namely $t$-test and the ANOVA analysis were applied in order to explain the relationship between the variables and the features of a sample population. The findings show that most hypotheses in the study are supported. In conclusion, it is believed that MPRHEIs require strong support from the stakeholders particularly the students' perception where their inputs regarding the service quality of MPRHEIs are appreciated as it has the potential of leading MPRHEIs to achieve significant sustainability in this region. It is also suggested for future researches to examine the perception of academicians and other stakeholders towards the quality of services in higher education in order to build sustainable MPRHEIs.
\end{abstract}

Keywords: Higher education, inferential statistics, perception, service quality, sustainability.

\section{Introduction}

The Malaysian government is determined to set up a vision for developing better higher education with the vision of making Malaysia as a hub of excellence for Higher Education by 2020 (Zain et al., 2017). Aligned with such vision, the Ministry of Education Malaysia has designed various frameworks and plans for the higher education sector that contain specific objectives for institutions of higher learning. These objectives include improving the teaching and learning quality, reinforcing innovation and research, empowering higher education institutions (HEIs), and intensifying internationalisation (Zain et al., 2017).

For these objectives to be achieved, it is necessary for a set of benchmarks to be established that governs the practices in HEIs. Nevertheless, the establishment of such benchmarks should address the interests and opinions of various stakeholders who subscribe to the services offered by universities and other HEIs. One of the largest stakeholders in HEIs is students. In this regard, the perceptions from students serve as an important indicator where their positive perceptions imply that the objectives of higher education are being achieved because students are said to be the main consumers of higher educational institutions (Brennan \& Eagle, 2007; Gruber, Fuß, Voss, \& Gläser-Zikuda, 2010; Zangoueinezhad \& Moshabaki, 2011). Most HEIs have begun to realise that students are among the important stakeholders of HEIs and that their perception on satisfaction is crucial (Letcher \& Neves, 2010; Guilbault, 2016). This leads the management and the academics of HEIs to believe in the necessity of understanding students' wants and needs.

The need for benchmarking is strengthened by the inherent pressure of increased competition 
in the educational service sector. On the other hand, higher education institutions should also focus and be involved in various ways to promote sustainability (Shephard, 2008) and improve institutions ranking (Kehm, 2014). With the need to implement higher education sustainability, HEIs may expect to face several challenges, which require the stakeholders' involvement in various ways (Stephens, Hernandez, Román, Graham, \& Scholz, 2008). The motivation for this study is integrating the service quality management of Malaysia Public Research Higher Education Institutions (MPRHEIs) and its sustainability, and thus, this paper aims to examine how the differences in gender, nationality, and educational level shall influence the perception towards the educational attributes of teaching quality, research quality, and internationalisation quality of MPRHEIs. This study fills the gap by exploring the perceived quality services on variables related to the educational attributes of teaching quality, research quality, and internationalisation quality (Padlee et al., 2019) from the setting of students' characteristics which has never been studied before.

\section{Literature Review}

Numerous efforts have been invested to achieve the goals of the nation's educational philosophy. This includes the effort to help the tertiary (university) sector to build a strong reputation, gain the ability to be dynamic and competitive, and able to compete and grow at the global level. For such goals to be achieved, Malaysian universities need to improve their services for competitive advantage that will attract future students and retain existing students (Ali et al., 2016). Students are among the important assets of any educational institutes in terms of maintaining the performance of the institution (Abdul Rahman et al., 2004; Woodall, Hiller, \& Resnick, 2014). The measurement of students' perceptions towards their university experience is thus fundamental for educational institutions to identify their strengths and weaknesses in order to improve their performance (Brennan \& Eagle,
2007). The quality of service in the education sector is hard to be measured as it involves assessing the quality of the lecturers, research output, creation of knowledge (researchers and students), and the achievements of the university (Mouritsen et al., 2005). Nevertheless, this task is important and this study therefore seeks to understand and evaluate the students' perception of Malaysian research universities by analysing the perceptions of university students about the service quality on teaching, research, and internationalisation quality.

\section{Sustainability of Service Quality in Higher Education Services}

Stamenkov \& Dika (2015) define sustainable service quality as the ability for services to deliver quality services continuously to all customers in order to manage and maintain their satisfaction and loyalty. Numerous studies have investigated on the sustainability of service quality across various services including the higher education sector. In the higher education service, students are deemed as one the important stakeholders of higher education institution as they need to pay for their educational services (Bhuain, 2016). Thus, higher education institutions should focus on their needs and wants pertaining to educational services by providing excellent service quality (Bhuain, 2016). This study therefore adds to the discussion by focusing on the sustainability of maintaining and continuously serving the quality services of higher education institutions by including educational services such as teaching, research, and internationalisation service for the benefits of students' satisfaction (Ezeokoli \& Ayodele, 2015; Senthilkumar, \& Arulraj, 2011). By sustaining service quality, higher education institutions will be marketable and subsequently attract prospective students from the local and international market.

\section{The Service Quality of the Educational Attributes of Universities}

The service quality of educational attributes is an important issue for universities. "Quality in a service organization is a measure of the 
range to which the service delivered meets the customer's expectations" (Yousapronpaiboon, 2014, p. 1089). Harvey \& Knight (1996) mention that the quality of service for higher education should reflect exceptional standard, consistency, fitness for purpose, value for money, and transformative. But as mentioned by Nadiri, Kandampully \& Hussain (2009), “In measuring service quality in higher education, it is important to study the meaning of service quality that relates to the situation under study". The growing need to quantify the quality parameters in this sector has led to numerous researches (Chen, Wang \& Yang, 2019; Ali et al., 2016; Cattaneo, Meoli, \& Signori, 2014; Kim, Lim, \& Lee, 2014; Phusavat, Ketsarapong, Ranjan, \& Lin, 2011; Arambewela \& Hall, 2009) especially identity and reputation, have received considerable attention in recent years, research efforts have mainly focused on those allied constructs and not on their interplay with related constructs. This study examines two models to explore the relationships among service quality, facilities, student satisfaction, image of the university college, and image of the study program, with student loyalty as the ultimate dependent variable. The students perceive the image of the university college and the image of the study program as two distinct concepts. The studylu2019 s preferred model only indirectly relates the image of the study program to student loyalty (via the image of the university college that investigated on various education attribute of services. The service qualities investigated in this study are teaching quality, research quality, and internationalisation quality.

\section{Teaching Quality}

Teaching quality refers to the comparison between students' perceptions and expectations on the curriculum, instruction, and assessment in the teaching services that they receive (Yin et al., 2016). As teaching is the main service offered by universities to its customers (students), the quality of teaching from the students' perspective should be taken seriously to ensure the good performance of the universities. According to Chen et al. (2009) performance measure indicators (PMIs, a university that has excellent lecturers will produce excellent students. In return, these students will show their loyalty by promoting their alma mater, which leads to positive word of mouth to the university's reputation. Furthermore, Yin et al. (2014) suggest that lecturers should pay attention to the aspects of learning as it is the factor that often receives criticism from students. Academic quality describes the learning opportunities that help students to gain their degree by ensuring that there are appropriate teaching, support, assessment, and learning opportunities. Findings by Ellis (1993) also posit that areas for improvement can be achieved through the dissemination of excellent learning and teaching practices. This suggests that universities need to follow several approaches in setting quality assurance guidelines that serve as a system of quality assurance for learning and teaching.

\section{Research Quality}

Research quality describes the provision of good quality research by universities and its influence to the universities' performance (Cadez et al., 2017). With the ongoing interest in research productivity and ranking of universities (Damme, 2001; Hicks, 2012), Ciriaci \& Muscio (2014) report that the research quality of universities will influence the graduates' employability and subsequently be the factor for prospective students to choose their preferred university. This emphasises the importance of quality research rankings due to its potential benefits to attract and retain students. Nevertheless, Korhonen (2001) highlights on the difficulty to measure the quality of research as each university has different approaches. Excellent researchers also tend to work at renowned universities and produce good quality research, which benefits the universities in terms of its generated income and prestige (Goodall, 2006). Furthermore, researches produced by universities often involve collaboration with other universities or institutions. These collaborative actions can be viewed as helping to improve the universities' performance through the transfer of knowledge among the researchers. The research quality of 
a university can be measured by converting its research output (including collaborations with universities, the public sector, related sectors, and international cooperation), publication of papers in conference proceedings, and the total number of higher degrees completed into the composite index (Lee, 2011).

\section{Internationalisation Quality}

Internationalization of a university refers to "the multiple activities, programs, and services that fall within international studies, international educational exchange, and technical cooperation" (Arum \& Van de Water, 1992, p. 202). Knight (2004) in Guo \& Guo (2017) mentioned that internationalisation is the series of international activities (e.g. academic mobility of students and faculty), international linkages and partnerships, and new international academic programmes and research initiatives. The provision of services of an international standard and the portray of an international image are the criteria for prospective students to choose their preferred higher education institutions (Maria et al., 2006). Hence, the quality of internationalisation services in universities is important and should never be neglected as these services may influence current and prospective international students.

\section{Students Characteristics}

Research on students' characteristics is crucial as their different characteristics may result in different perception, level of satisfaction, and behavioural intention towards the services of MPRHEIs. In this study, student characteristic is explained by the demographic background of students/respondents such as gender, age, race and others. Thus, there is a need to better understand the market of students from different characteristics as this may lead to proactive actions in providing services to meet their specific needs (Akanwa, 2015; Walsh, Evanschitzky, \& Wunderlich, 2008). It may also assist in setting the strategies to attract and retain students for a university (Douglass \& Edelstein, 2009). Therefore, this study investigates the potential of three characteristics (i.e. nationality, gender and academic level) to influence students' perception on the services offered by MPRHEIs.

\section{Nationality}

A number of studies have investigated whether stunumber of studies have investigated whether students' nationality influences their perception and satisfaction towards the quality of services at universities. This includes Ali et al. (2016) who report that students from different countries have different perceptions and level of satisfaction towards the service quality at their respective universities. Meanwhile, the study by Gamage et al. (2008) found that Japanese and Thai students have shown different perceptions and level of satisfaction to the three services in the university, namely academic services, nonacademic services, and facilities. Nevertheless, limited studies have investigated whether students' nationality influences their perception to the teaching quality, research quality, and internationalisation quality of MPRHEIs. The hypotheses of the study are as follows:

H1a: Students' nationality significantly influences their perception to the teaching quality of MPRHEIs.

H1b: Students' nationality significantly influences their perception to the research quality of MPRHEIs.

H1c: Students' nationality significantly influences their perception to the internationalisation quality of MPRHEIs.

\section{Gender}

Previous studies have proven that gender may provide different perceptions to service quality and level of satisfaction. In the context of university, the study by Sumaedi et al. (2012) found that there is a significant difference of perceived quality on social activities while the perceptions on other attributes remain similar. Meanwhile, Joseph et al. (2005) report that female students place greater emphasis on the physical and location aspects of a university as compared to male students. The findings 
of previous studies as well as the importance of studying the differences on service quality perception between female and male students lead to the development of the following hypotheses:

H2a: Students' gender significantly influences their perception to the teaching quality of MPRHEIs.

H2b: Students' gender significantly influences their perception to the research quality of MPRHEIs

H2c: Students' gender significantly influences their perception to the internationalisation quality of MPRHEIs.

\section{Academic Level}

Education has the potential to influence various aspects of human life (Baker, AlGahtani, \& Hubona, 2007) including our attitudes and behaviour (Metle, 2003). Existing studies have found that academic level does influence students' attitudes where postgraduate students demonstrate different satisfaction to their university experience as compared to the undergraduates (Taylor, 2002). This study therefore investigates how different academic level shall affect students' academic level towards the service quality on teaching, research and internationalisation. Hence, the following hypotheses are developed:

H3a: Students' academic level significantly influences their perception to the teaching quality of MPRHEIs.
H3b: Students' academic level significantly influences their perception to the research quality of MPRHEIs

H3c: Students' academic level significantly influences their perception to the internationalisation quality of MPRHEIs.

\section{Methodology}

This study employs the quantitative research design through the use of the survey method. It involves respondents from five key research universities in Malaysia. The selection was based on the universities' inclusion in the list of QS top 200 universities in the world (QS, 2019). Statistics from the Ministry of Higher Education Malaysia report that the five universities had recorded an enrolment of 140,735 students in 2018. Table 1 shows the total number of students' enrolment in each university.

Based on the total population of 146,735 students, the method by Krejcie \& Morgan (1970) was used to determine the size of sample required for the study. This was followed by a simple random sampling (Chua, 2006; Sekaran, 2003) in order to select the respondents who comprised undergraduates in their second year and above as well as local and international postgraduates. The faculties in each university were contacted to obtain the name list of students. The students were then approached by the appointed enumerators in order to get their consent to answer the questionnaire. Eventually, the questionnaires were distributed to 500 respondents and 418 questionnaires were returned with a response rate of $83.6 \%$.

Table 1: Number of enrolment

\begin{tabular}{clc}
\hline No. & \multicolumn{1}{c}{ Name of Public HEI } & Student population \\
\hline 1 & UM - Universiti Malaya & 27,960 \\
2 & USM - Universiti Sains Malaysia & 29,173 \\
3 & UKM - Universiti Kebangsaan Malaysia & 30,874 \\
4 & UPM - Universiti Putra Malaysia & 29,025 \\
5 & UTM - Universiti Teknologi Malaysia & 29,703 \\
& Total & $\mathbf{1 4 6 7 3 5}$ \\
\hline \hline
\end{tabular}

Source: Number of Students Enrolment in Public HEIs (MOHE, 2018) 
However, only 412 questionnaires were valid and included for data analysis.

A pre-testing was conducted to determine whether the chosen scales have the ability to investigate the relationship between each of the construct. The reliability test shows that all constructs have obtained the Cronbach Alpha of above 0.7. According to Hair et al. (2017), the Cronbach Alpha values are considered as acceptable if it achieves the 0.7 threshold. For this study, self-administered questionnaire was chosen as the data collection method. The development of the questionnaire is represented by multiple items based on previous studies (Chen, Wang \& Yang, 2019; Ali et al., 2016; Phusavat, Ketsarapong, Ranjan, \& Lin, 2011; Cattaneo, Meoli, \& Signori, 2014; Kim, Lim, \& Lee, 2014; Arambewela \& Hall, 2009)especially identity and reputation, have received considerable attention in recent years, research efforts have mainly focused on those allied constructs and not on their interplay with related constructs. This study examines two models to explore the relationships among service quality, facilities, student satisfaction, image of the university college, and image of the study program, with student loyalty as the ultimate dependent variable. The students perceive the image of the university college and the image of the study program as two distinct concepts. The study lu2019 s preferred model only indirectly relates the image of the study program to student loyalty (via the image of the university college that are used to describe, conceptualise, and operationalize the main constructs of the study (i.e teaching quality, research quality, and internationalisation quality). A sevenpoint rating scale that ranges from 1 (strongly disagree) to 7 (strongly agree) was used to measure the students' perception. The data collection was done by enumerators who were selected among the students or research assistants at each university. The data collection process was conducted from September 2015 to February 2016. The questionnaires were sent via post or delivered by hand to the enumerators.

The principal component analysis with varimax rotation has produced results that indicate an underlying structure of 3 factors capable of explaining $60.086 \%$ of the cumulative variance of all items. For this study, a factor loading greater than 0.6 was chosen. Table 2 shows the rotated component matrix of the factor analysis variable where those below 0.6 were excluded.

Table 2: Rotated Component Matrix

\begin{tabular}{llcc}
\hline & & Factor & 2 \\
\hline b10 & $\begin{array}{l}\text { There is a pleasant teaching and learning environment } \\
\text { b11 }\end{array}$ & $\begin{array}{l}\text { Knowledge is transmitted between lecturers and students } \\
\text { during class }\end{array}$ & 0.750 \\
b12 & $\begin{array}{l}\text { Students' skill levels are enhanced (e.g. problem solving, } \\
\text { critical thinking) }\end{array}$ & 0.739 \\
b07 & $\begin{array}{l}\text { Up-to-date teaching materials are used by lecturers (e.g. } \\
\text { books, magazines, journals) }\end{array}$ & 0.736 \\
b02 & $\begin{array}{l}\text { Appropriate methods of learning are used in class (e.g. } \\
\text { seminar, group discussion) }\end{array}$ & 0.711 \\
b05 & $\begin{array}{l}\text { The lecturers show their professionalism as lecturers } \\
\text { b04 }\end{array}$ & $\begin{array}{l}\text { Sophisticated technology is used in the teaching and learning } \\
\text { process (e.g. e-learning) }\end{array}$ & 0.690 \\
b01 & $\begin{array}{l}\text { There is effective interaction between the lecturers and } \\
\text { students in class }\end{array}$ & 0.678 \\
\hline
\end{tabular}




\begin{tabular}{|c|c|c|c|c|}
\hline b08 & The lecturer is committed to lifelong learning & 0.673 & & \\
\hline b06 & The course content is solid & 0.672 & & \\
\hline b03 & The lecturer gives full assistance to students during class & 0.668 & & \\
\hline b09 & There is an ideal student to staff ratio & 0.622 & & \\
\hline b31 & $\begin{array}{l}\text { The university is recognised worldwide and has a global } \\
\text { reputation }\end{array}$ & & 0.800 & \\
\hline b26 & $\begin{array}{l}\text { The university's academic certificates are recognised at the } \\
\text { international level }\end{array}$ & & 0.766 & \\
\hline b25 & $\begin{array}{l}\text { The university has a strong position as a study destination for } \\
\text { international students }\end{array}$ & & 0.735 & \\
\hline b24 & $\begin{array}{l}\text { There is mutual recognition between the university and } \\
\text { international universities }\end{array}$ & & 0.732 & \\
\hline b30 & $\begin{array}{l}\text { The university offers a variety of programmes for } \\
\text { international students }\end{array}$ & & 0.729 & \\
\hline b27 & $\begin{array}{l}\text { The university is renowned for its excellent academic staff at } \\
\text { the international level }\end{array}$ & & 0.716 & \\
\hline b29 & $\begin{array}{l}\text { The university provides outstanding services for international } \\
\text { students }\end{array}$ & & 0.704 & \\
\hline b28 & $\begin{array}{l}\text { The university is renowned for its academic excellence at the } \\
\text { international level }\end{array}$ & & 0.694 & \\
\hline b19 & $\begin{array}{l}\text { There is a good number of patented commercial products that } \\
\text { are marketable }\end{array}$ & & & 0.792 \\
\hline b15 & $\begin{array}{l}\text { There is research collaboration with renowned research } \\
\text { universities }\end{array}$ & & & 0.736 \\
\hline b14 & There is research collaboration with local universities & & & 0.717 \\
\hline b16 & There is research collaboration with industry & & & 0.713 \\
\hline b18 & $\begin{array}{l}\text { Good-quality articles published in top journals and } \\
\text { proceedings }\end{array}$ & & & 0.704 \\
\hline b17 & There is research collaboration with foreign institutions & & & 0.658 \\
\hline \multirow[t]{4}{*}{ b20 } & There is a good number of publications per lecturer & & & 0.615 \\
\hline & Cronbach's alpha & 0.930 & 0.906 & 0.922 \\
\hline & $\%$ of variance & 45.506 & 8.806 & 5.773 \\
\hline & Cumulative \% & 45.506 & 54.312 & 60.086 \\
\hline
\end{tabular}

Notes: Extraction method $=$ principal component analysis; rotation method $=$ varimax with Kaiser normalisation; rotation converged in six iterations.

\section{Inferential Analysis}

Inferential statistics are used to explain the relationship between the variables and to explain the features of a sample population. In this study, the $t$-test and ANOVA analyses were used:

a) $t$-test

This study uses the independent-sample $t$-test and paired-sample $t$-test where one sample is measured twice and the measurement data is used to make comparisons (Chua, 2006). The analysis employs the independent-sample $t$-test in order to analyse $\mathrm{H} 1$ and $\mathrm{H} 2$ to measure the mean difference on nationalities and gender. 


\section{b) ANOVA}

ANOVA is used to differentiate and compare more than two means and can be performed simultaneously on two or more independent variables. In this study, oneway ANOVA was used to test the significant mean difference between academic level and represented by $\mathrm{H} 3$ of the study. For the purpose of post hoc testing, the Tukey honestly significant difference (HSD) test was utilised due to its more conservative approach in detecting significant differences.

\section{Results}

An independent $t$-test was conducted to determine the impact of nationality on the students' perception to the educational attributes of the three services. The students' nationalities are classified into two groups: local (Malaysian) and international (other countries). The $t$-test results are provided in Table 3 .

The results indicate that there is no significant difference between the mean scores of the local and international nationality groups in relation to the perception of teaching quality $(t=1.657, \mathrm{p}=0.90)$. There is also no significant difference in the perception of research quality based on the mean scores of the two nationality groups $(t=0.569, \mathrm{p}=0.569)$ with the mean difference being higher for local students than international students. Finally, there is a significant difference in the perception of internationalisation quality according to the mean scores of the two nationality groups $(t$ $=2.040, \mathrm{p}=0.001)$ with the mean difference being higher for local students than international students.

Table 4 presents the results of the independent $t$-test that assesses the impact of gender on students' perception to the educational attributes of services provided by MPRHEIs.

The results in Table 4 indicate that there is no significant difference in the perception of teaching quality, research quality and internationalisation quality according to the mean scores of the two gender groups $(t=1.207$, $\mathrm{p}=0.072 ; t=0.275, \mathrm{p}=0.783 ; \mathrm{t}=0.427, \mathrm{p}=$ $0.547)$.

Further exploratory analysis was conducted on the aggregate data set by using a one-way ANOVA and, where appropriate, a post hoc Tukey's HSD test. Table 5 shows the one-way ANOVA results and Table 6 shows the post hoc Tukey's HSD test results.

Following the one-way ANOVA which tested the mean differences between the level

Table 3: $t$-test Result for Impact of Nationality on Perception of Educational Attributes of Services

\begin{tabular}{llcccccc}
\hline \multicolumn{1}{c}{$\begin{array}{c}\text { Students' } \\
\text { perception }\end{array}$} & \multicolumn{1}{c}{ Country } & N & Mean & $\begin{array}{c}\text { Std. } \\
\text { deviation }\end{array}$ & df & t-value & Sig. (P) \\
\hline Teaching quality & $\begin{array}{l}\text { Local } \\
\text { student }\end{array}$ & 323 & 5.823 & 0.853 & 410 & 1.657 & 0.090 \\
& $\begin{array}{l}\text { International } \\
\text { student }\end{array}$ & 89 & 5.647 & 1.009 & & & \\
Lesearch quality & $\begin{array}{l}\text { Local } \\
\text { student }\end{array}$ & 323 & 5.650 & 0.897 & 410 & 0.569 & 0.569 \\
& $\begin{array}{l}\text { International } \\
\text { student }\end{array}$ & 89 & 5.587 & 1.025 & & & \\
Internationalisation \\
quality & $\begin{array}{l}\text { Local } \\
\text { student }\end{array}$ & 323 & 5.542 & 0.911 & 410 & 2.040 & 0.001 \\
& $\begin{array}{l}\text { International } \\
\text { student }\end{array}$ & 89 & 5.306 & 1.139 & & & \\
\hline
\end{tabular}

Notes: Significant at the 0.05 level. 
of study, the results show that there is no significant difference in the mean of perception towards teaching quality $(\mathrm{F}=1.534, \mathrm{p}=0.205)$ or internationalisation quality $(\mathrm{F}=0.241, \mathrm{p}=$ 0.868). On the other hand, there is a significant difference in the mean for the perception towards research quality $(\mathrm{F}=4.898, \mathrm{p}=0.002)$. An additional post hoc analysis was conducted using the Tukey's HSD post hoc test and the results indicate that the mean differences between the groups are $r=0.229, \mathrm{p}=0.031$. Specific differences as indicated by the Tukey's HSD post hoc comparison are detailed in Table 6 .

An additional post hoc analysis was conducted using the Tukey's HSD post hoc test and the results indicate that the mean differences between the groups are $r=0.229$, $\mathrm{p}=0.031$. Specific differences as indicated by the Tukey's HSD post hoc comparison are detailed in Table 6.

Table 4: $t$-test Result for Impact of Gender on Perception of Educational Attributes of Services

\begin{tabular}{llllclcc}
\hline Students' Perception & Gender & N & Mean & $\begin{array}{c}\text { Std. } \\
\text { Deviation }\end{array}$ & df & t-value & Sig. (P) \\
\hline \multirow{2}{*}{ Teaching quality } & Male & 121 & 5.867 & 0.826 & 410 & 1.207 & 0.072 \\
& Female & 291 & 5.751 & 0.915 & & & 0.783 \\
Research quality & Male & 121 & 5.656 & 0.816 & 410 & 0.275 & 0.547 \\
Internationalisation & Female & 291 & 5.628 & 0.968 & & & \\
quality & Female & 291 & 5.478 & 0.98 & & & \\
\hline
\end{tabular}

Notes: Significant at the 0.05 level.

Table 5: ANOVA Result for Impact of Educational level on Perception of Educational Attributes of Services

\begin{tabular}{llcccc}
\hline \multicolumn{1}{c}{ Students' Perception } & Mean & $\begin{array}{c}\text { Std. } \\
\text { Deviation }\end{array}$ & F & Sig. \\
\hline \multirow{4}{*}{ Teaching quality } & Bachelor's degree & 5.672 & 0.955 & 1.534 & 0.205 \\
& Master's degree & 5.895 & 0.795 & & \\
& PhD & 5.792 & 0.893 & & \\
& Other & 5.815 & 1.279 & & \\
& Bachelor's degree & 5.412 & 0.923 & 4.898 & 0.002 \\
Research quality & Master's degree & 5.778 & 0.873 & & \\
& PhD & 5.725 & 0.943 & & \\
& Other & 6.1 & 0.989 & & \\
Internationalisation & Bachelor's degree & 5.454 & 0.988 & 0.241 & 0.868 \\
quality & Master's degree & 5.504 & 0.926 & & \\
& PhD & 5.509 & 0.984 & & \\
& Other & 5.78 & 1.424 & & \\
\hline
\end{tabular}

Note: ANOVA result $\operatorname{Sig}=\mathrm{p} \leq 0.05$; sample size $=412$. 
Table 6 shows that there is a difference between the bachelor's degree students and other respondents (master's, $\mathrm{PhD}$, and others) where the bachelor's degree students perceive the quality of research in differing view. This finding is consistent with the proposition that students who are studying for a bachelor's degree have less experience of research quality, which thus affects their judgement of research quality. Meanwhile, the others students (diploma and exchange students) also assign a lower value to the quality of research. This is because exchange students are not involved with the research activities in a university and have less or no experience in this dimension.

\section{Discussion and Conclusion}

The objective of this study is to examine how the differences in nationality, gender, and educational level influence the students' perception to the educational attributes of teaching quality, research quality, and internationalisation quality of MPRHEIs.

The results on nationality show that $\mathrm{H} 1 \mathrm{a}$ and $\mathrm{H} 1 \mathrm{~b}$ are rejected and $\mathrm{H} 1 \mathrm{c}$ is supported. The importance to determine whether nationality influences students' perception towards educational service attributes originates from the probability that students who go overseas may compare their service quality perceptions especially with their own country (Turan Katircioglu et al., 2012). The results indicate that the perceptions towards the internationalisation quality are significant with nationality. Meanwhile, the quality of teaching and research have no significant relationship with nationality. There are two possible implications that can stem from this finding. First, the education system that exists in every country is different. For example, the number of students per teaching and learning session varies across countries. In addition, the techniques and course contents are also different. Second, the language used as the medium of instruction is not well-mastered which makes the teaching and learning process difficult. Furthermore, it is believed that local students have different perceptions than international students as they can easily accept the services provided to them. Whilst, international students can be critical to the services that they experience as they pay

Table 6: Results of Tukey's HSD Post Hoc Test for Students' Perception to Research Quality

\begin{tabular}{lllcc}
\hline (I) Academic Level & (J) Academic Level & $\begin{array}{c}\text { Mean } \\
\text { difference } \\
\text { (I - J) }\end{array}$ & Std. error & Sig. \\
\hline Bachelor's degree & Master's degree & -0.365 & 0.107 & 0.004 \\
& PhD & -0.313 & 0.113 & 0.029 \\
Master's degree & Other & -0.687 & 0.415 & 0.348 \\
& Bachelor's degree & 0.365 & 0.107 & 0.004 \\
PhD & PhD & 0.052 & 0.114 & 0.967 \\
& Other & -0.321 & 0.415 & 0.866 \\
& Bachelor's degree & 0.313 & 0.113 & 0.029 \\
Other & Master's degree & -0.052 & 0.114 & 0.967 \\
& Other & -0.374 & 0.418 & 0.806 \\
& Bachelor's degree & 0.688 & 0.415 & 0.348 \\
& Master's degree & 0.322 & 0.415 & 0.866 \\
& PhD & 0.374 & 0.418 & 0.806 \\
\hline
\end{tabular}

Notes: Dependent variable $=$ perception of research quality; sig level $=p \leq 0.05$. 
for the service and thus expecting more in the service that they receive (Ali et al., 2016).

On the other hand, there is no significant difference between female and male students with respect to their perception towards teaching quality, research quality and internationalisation quality. In this case, $\mathrm{H} 2 \mathrm{a}, \mathrm{H} 2 \mathrm{~b}$ and $\mathrm{H} 2 \mathrm{c}$ are rejected. A possible explanation for this finding is that female and male students have similar views to the perception of what constitutes quality of services. This findings contradict from most previous where male students tend to have higher perceptions and sensitivity towards the quality of services as compared to female students (Joung et al., 2016; Omar et al., 2016). Nevertheless, the findings can be used to improve the service delivery based on gender difference (Lee et al., 2011).

Meanwhile, the results for the perception of educational level show that H3a and H3c are rejected and $\mathrm{H} 3 \mathrm{~b}$ is accepted. The ANOVA analysis indicates that the students' perception towards research quality varies according to their educational level. The post hoc Tukey test results further reveal that the difference is due to $\mathrm{PhD}$ students assigning a higher level of perception than their counterparts of other education levels. This result is consistent with the proposition that $\mathrm{PhD}$ students often differ from other students in their perception to the educational attributes of services because of their greater experience on these attributes which influences their judgements (Taylor, 2001). This is aligned with Douglas et al. (2006) who highlight on the importance of teaching experience. However, this study shows that there is no significant relationship between teaching quality and educational level as most postgraduate programmes in Malaysian research universities are research-based rather than lecture-based.

In conclusion, managers in MPRHEIs must take into account the factors that may influence students' perceived quality. The failure to meet such expectation may inflict negative reputations to the MPRHEIs' image and eventually affects the students' behavioural intentions. It is also recommended for managers of MPRHEIs to allocate appropriate resources and strengthen their policies in quality services. This can be achieved by looking at different characteristics of the students which will allow MPRHEIs to develop different segmentation strategies. This study is conducted only at MPRHEIs and thus cannot be generalised to all public universities in Malaysia. Therefore, further analysis can be done by including more public universities as part of the sample in order to generate more inclusive findings. The findings of this study also contribute to the literature and pool of knowledge in the field of service quality of MPRHEIs towards sustainability.

\section{Acknowledgments}

This work was supported by the Ministry of Higher Education Malaysia under Project RAGS 2015, Project Number 57111.

\section{References}

Abdul Rahman, H., Khalifah, Z., Arif, S., Sirin, R., Zainal Abidin, H., \& Sulong, N. (2004). Kajian mengenai tahap kualiti pendidikan tinggi dari perspektif pelajar di Universiti Teknologi Malaysia. Pusat Pengajian Penyelidikan Universiti Teknologi Malaysia.

Ahmad, S. Z. (2015). Evaluating student satisfaction of quality at international branch campuses. Assessment \& Evaluation in Higher Education, 40(4), 488-507. https://doi.org/10.1080/02602938.2014.92 5082

Akanwa, E. E. (2015). International students in western developed countries: History, challenges, and prospects. Journal of International Students, 5(3), 271-284.

Ali, F., Zhou, Y., Hussain, K., Nair, P. K., \& Ragavan, N. A. (2016). Does higher education service quality effect student satisfaction, image and loyalty? A study of international students in Malaysian public universities. Quality Assurance in 
Education, 24(1), 70-94. http://dx.doi. org/10.1108/QAE-02-2014-0008

Arambewela, R., \& Hall, J. (2009). An empirical model of international student satisfaction. Asia Pacific Journal of Marketing and Logistics, 21(4), 555-569. https://doi. org/10.1108/13555850910997599

Arum, S., \& Van de Water, J. (1992). The need for a definition of international education in U.S. universities. In C. Klasek (Ed.), Bridges to the futures: Strategies for internationalizing higher education. IL: Association of International Education Administrators.

Bhuian, S. N. (2016). Sustainability of Western branch campuses in the Gulf Region: Students' perspectives of service quality. International Journalof Educational Development, 49, 314-323. https://doi. org/10.1016/j.ijedudev.2016.05.001

Brennan, R., \& Eagle, L. (2007). Are students customers? TQM and marketing perspectives. Quality Assurance in Education, 15(1), 44-60.

Cadez, S., Dimovski, V., \& Zaman Groff, M. (2017). Research, teaching and performance evaluation in academia: The salience of quality. Studies in Higher Education, 42(8), 1455-1473. https://doi.org/10.1080/030750 79.2015.1104659

Cattaneo, M., Meoli, M., \& Signori, A. (2014). Performance-based funding and university research productivity: The moderating effect of university legitimacy. The Journal of Technology Transfer, 41(1), 85-104. https://doi.org/10.1007/s1096

Chen, S., Wang, H., \& Yang, K. (2009). Establishment and application of performance measure indicators for universities. The TQM Journal, 21(3), 220-235. https://doi. org/10.1108/17542730910953004

Chua, L. C. (2006). Sample size estimation using Krejcie and Morgan and Cohen Statistical Power Analysis: A comparison. Jurnal Penyelidikan IPBL, 7, 78-86.
Ciriaci, D., \& Muscio, A. (2014). University choice, research quality and graduates' employability: Evidence from Italian national survey data. European Educational Research Journal, 13(2), 199-219. https:// doi.org/10.2304\%2Feerj.2014.13.2.199

Creswell,J.W., \& Creswell, J.D.(2017). Research design: Qualitative, quantitative, and mixed methods approaches. Sage publications.

Douglas, J., Douglas, A., \& Barnes, B. (2006). Measuring student satisfaction at a UK university. Quality Assurance in Education, 14(3), 251-267.

Douglass, J. A., \& Edelstein, R. (2009). The global competition for talent: The rapidly changing market for international students and the need for a strategic approach in the US. Research \& Occasional Paper Series. CSHE. 8.09. Center for Studies in Higher Education.

Einarson, M. K., \& Matier, M. W. (2005). Exploring race differences in correlates of seniors' satisfaction with undergraduate education. Research in Higher Education, 46(6), 641-676. https://doi. org/10.1007/s11162-004-4138-0

Ellis, R. (1993). The management of quality in the University of Ulster. Higher Education, 25(3), 239-257. https://doi.org/10.1007/ $\mathrm{BF} 01383853$

Ezeokoli, R. N., \& Ayodele, K. O. (2015). Dimensions of service quality encountered by students on sustainability of higher education in Nigeria. Developing Country Studies, 4(6), 147-156.

Gamage, D. T., Suwanabroma, J., Ueyama, T., Hada, S., \& Sekikawa, E. (2008). The impact of quality assurance measures on student services at the Japanese and Thai private universities. Quality assurance in Education, 16(2), 181-198.

Goodall, A. H. (2006). Should top universities be led by top researchers and are they? A citations analysis. Journal of Documentation, 62(3), 388-411. 
Gruber, T., Fuß, S., Voss, R., \& Glaser-Zikuda, M. (2010). Examining student satisfaction with higher education services: Using a new measurement tool. International Journal of Public Sector Management, 23(2), 105-123.

Guilbault, M. (2016). Students as customers in higher education: Reframing the debate. Journal of Marketing for Higher Education, 26(2), 132-142.

Guo, Y., \& Guo, S. (2017). Internationalization of Canadian higher education: Discrepancies between policies and international student experiences. Studies in Higher Education, 42(5), 851868. doi:10.1080/03075079.2017.1293874

Hair, Jr., J. F., Sarstedt, M., Ringle, C. M., \& Gudergan, S. P. (2017). Advanced issues in partial least squares structural equation modeling. SAGE Publications.

Hair, Jr., J. F., Wolfinbarger, M., Money, A. H., Samouel, P., \& Page, M. J. (2015). Essentials of business research methods. Routledge.

Harman, G. (2005). Internationalization of Australian higher education: A critical review of literature and research. In Internationalising higher education (pp. 119-140). Netherlands: Springer.

Harvey, I., \& Knight, P. (1996). Transforming higher education. Buckingham and London: Society for Research into Higher Education \& Open University Press,

Hicks, D. (2012). Performance-based university research funding systems. Research Policy, 41(2), 251-261. https://doi. org/10.1016/j.respol.2011.09.007

Hoyer, W. D., \& MacInnis, D. J. (2006). Consumer behavior (4th ed.). Boston, MA: Houghton Mifflin. https://doi. org/10.1108/09684880710723025

Jayawardena, C. (2001). Challenges in international hospitality management education. International Journal of Contemporary Hospitality Management, 13(6), 310-315. https://doi. org/10.1108/EUM0000000005967
Joseph, M., Yakhou, M., \& Stone, G. (2005). An educational institution's quest for service quality: customers' perspective. Quality AssuranceinEducation, 13(1),66-82.https:// doi.org/10.1108/09684880510578669

Joung, H.-W., Choi, E.-K., \& Wang, E. (2016). Effects of perceived quality and perceived value of campus foodservice on customer satisfaction: Moderating role of gender. Journal of Quality Assurance in Hospitality \& Tourism, 17(2), 101-113. https://doi. org/10.1080/1528008x.2015. 1042620

Kehm, B. M. (2014). Global university rankings-Impacts and unintended side effects. European Journal of Education, 49(1), 102-112.

Kementerian Pengajian Tinggi Malaysia. (KPTM) (2007). Pelan strategik (pp.142155).

Kim-soon, N., Rahman, A., \& Visvalingam, L. (2014). SERVQUAL: Can it be used to differentiate guest's perception of service quality of 3 star from a 4 star hotel. International Business Research, 7(7), 3747. http://dx.doi.org/10.5539/ibr.v7n7p37

Knight, Jane. (2004). Internationalization remodeled: Definition, approaches, and rationales. Journal of Studies in International Education, 8(1), 5-31. doi:10.1177/1028315303260832.

Korhonen, P. (2001). Value effciency analysis of academic research. European Journal of Operational Research, 130(2001), 121-132. https://doi.org/10.1016/S03772217(00)00050-3

Krejcie, R. V., \& Morgan, D. W. (1970). Determining sample size for research activities. Educational and Psychological Measurement, 30(3), 607-610. https://doi. org/10.1177\%2F001316447003000308

Lagrosen, S., Seyyed-Hashemi, R., \& Leitner, M. (2004). Examination of the dimensions of quality in higher education. Quality 
AssuranceinEducation, 12(2),61-69.https:// doi.org/10.1108/09684880410536431

Lee, B. L. (2011). Efficiency of research performance of Australian Universities: A reappraisal using a bootstrap truncated regression approach. Economic Analysis and Policy, 41(3), 195.

Lee, J. H., Kim, H. D., Ko, Y. J., \& Sagas, M. (2011). The influence of service quality on satisfaction and intention: A gender segmentation strategy. Sport Management Review, 14(1), 54-63. https://doi. org/10.1016/j.smr.2010.02.002

Letcher, D., \& Neves, J. (2010). Determinants of undergraduate business student satisfaction. Research in Higher Education Journal, $1-26$.

María Cubillo, J., Sánchez, J., \& Cerviño, J. (2006). International students' decision-making process. International Journal of Educational Management, 20(2), 101-115. https://doi. org/10.1108/09513540610646091

MOHE. (2018). QuickFacts2018 TERTIARY EDUCATION - HIGHER EDUCATION SECTOR. https://www.moe.gov.my/index. $\mathrm{php} / \mathrm{muat}$-turun/penerbitan-dan-jurnal/ terbitan/buku-informasi/1587-quick-facts2018-malaysia-educational-statistics-1/file

Mouritsen, J., Larsen, H. T., \& Bukh, P. (2005). Dealing with the knowledge economy: Intellectual capital versus balanced scorecard. Journal of Intellectual Capital, 6(1), 8-27. https://doi. org/10.1108/14691930510574636

Nadiri, H., Kandampully, J., \& Hussain, K. (2009). Students' perceptions of service quality in higher education. Total Quality Management \& Business Excellence, 20(5), 523-535. doi:10.1080/14783360902863713

Omar, M. S., Ariffin, H. F., \& Ahmad, R. (2016). Service quality, customers' satisfaction and the moderating effects of gender: A study of Arabic restaurants. Procedia-Social and Behavioral Sciences, 224, 384-392. https:// doi.org/10.1016/j.sbspro.2016.05.393
Padlee, S. F., Reimers, V., Mokhlis, S., Anuar, M. M., \& Ahmad, A. (2019). Keep up the good work in research universities: An importance-performance analysis. Australasian Marketing Journal $(A M J)$. (In press)

Phusavat, K., Ketsarapong, S., Ranjan, J., \& Lin, B. (2011). Developing a university classification model from performance indicators. Performance Measurement and Metrics, 12(3), 183-213. https://doi. org/10.1108/14678041111196668

Purbey, S., Mukherjee, K., \& Bhar, C. (2007). Performance measurement system for healthcare processes. International Journal of Productivity and Performance Management, 56(3), 241-251. https://doi. org/10.1108/17410400710731446

QS (2019). Top Universities Rankings in Malaysia. https://www.topuniversities.com/ universities/country/malaysia

Sekaran, U. (2003). Research methods for business. Hoboken.

Senthilkumar, N., \& Arulraj, A. (2011). SQM-HEI-determination of service quality measurement of higher education in India. Journal of Modelling in Management, 6(1), 60-78. https://doi. org/10.1108/17465661111112502

Shephard, K. (2008). Higher education for sustainability: Seeking affective learning outcomes. International Journal of Sustainability in Higher Education, 9(1), 87-98. https://doi. org/10.1108/14676370810842201

Shore, B. M., Pinker, S., \& Bates, M. (1990). Research as a model for university teaching. Higher Education, 19(1), 21-35. https://doi. org/10.1007/BF00142021

Stamenkov, G., \& Dika, Z. (2015). A sustainable e-service quality model. Journal of Service Theory and Practice, 25(4), 414-442. https://doi.org/10.1108/JSTP-09-20120103 
Stephens, J. C., Hernandez, M. E., Román, M., Graham, A. C., \& Scholz, R. W. (2008). Higher education as a change agent for sustainability in different cultures and contexts. International Journal of Sustainability in Higher Education, 9(3), 317-338. https://doi. org/10.1108/14676370810885916

Sumaedi, S., Mahatma Yuda Bakti, G., \& Metasari, N. (2012). An empirical study of state university students' perceived service quality. Quality Assurance in Education, 20(2), 164-183. https://doi. org/10.1108/09684881211219424

Taylor, J. (2001). The impact of performance indicators on the work of University academics: Evidence from Australian universities. Higher Education Quarterly, 55(1), 42-61. https://doi.org/10.1111/14682273.00173

Testa,M.R.,\&Mueller,S.L.(2009).Demographic and cultural predictors of international service worker job satisfaction. Managing Service Quality: An International Journal, 19(2), 195-210. https://doi. org/10.1108/09604520910943189

Turan Katircioglu, S., Mehtap-Smadi, S., Kilinç, C., \& Ünlücan, D. (2012). Service quality and university students' satisfaction on the travel agencies. International Journal of Quality and Service Sciences, 4(3), 299-311. https:// doi.org/10.1108/17566691211269602

Walsh, G., Evanschitzky, H., \& Wunderlich, M. (2008). Identification and analysis of moderator variables: Investigating the customer satisfactionloyalty link. European Journal of Marketing, 42(9/10), 977-1004. https://doi. org/10.1108/03090560810891109

Woodall, T., Hiller, A., \& Resnick, S. (2014). Making sense of higher education: Students as consumers and the value of the university experience. Studies in Higher Education.

Yavas, U., \& Babakus, E. (2010). Relationships between organizational support, customer orientation, and work outcomes: A study of frontline bank employees. International Journal of Bank Marketing, 28(3), 222-238. https://doi. org/10.1108/02652321011036477

Yin, H., Lu, G., \& Wang, W. (2014). Unmasking the teaching quality of higher education: students' course experience and approaches to learning in China. Assessment \& Evaluation in Higher Education, 39(8), 949-970. https://doi.org/10.1080/02602938 .2014 .880107

Yin, H., Wang, W., \& Han, J. (2016). Chinese undergraduates' perceptions of teaching quality and the effects on approaches to studying and course satisfaction. Higher Education, 71(1), 39-57. https://doi. org/10.1007/s10734-015-9887-5

Yousapronpaiboon, K. (2014). SERVQUAL: Measuring higher education service quality in Thailand. Procedia-Socialand Behavioral Sciences, 116, 1088-1095. https://doi. org/10.1016/j.sbspro.2014.01.350

Yousapronpaiboon, K. (2014). SERVQUAL: Measuring higher education service quality in Thailand. Procedia - Social and Behavioral Sciences, 116, 10881095. doi:10.1016/j.sbspro.2014.01.350

Yusoff, M., McLeay, F., \& Woodruffe-Burton, H. (2015). Dimensions driving business student satisfaction in higher education. Quality Assurance in Education, 23(1), 86-104. https://doi.org/10.1108/QAE-08-20130035

Zain, N. M.,Aspah, V.,Abdullah, N., \& Ebrahimi, M. (2017). Challenges and evolution of higher education in Malaysia. UMRANInternational Journal of Islamic and Civilizational Studies, 4(1-1).

Zangoueinezhad, A., \& Moshabaki, A. (2011). Measuring university performance using a knowledge-based balanced scorecard. International Journal of Productivity and Performance Management, 60(8), 824-843. 